\title{
AGING AND ELICITING AGENTS: EFFECT ON MURINE PERITONEAL MACROPHAGE MONOKINE BIOACTIVITY
}

\author{
Yifang Chen and SuzANNe F. BRADLeY \\ Divisions of Geriatric Medicine and Infectious Diseases, Department of Internal Medicine, University of \\ Michigan Medical School and Department of Veterans Affairs Medical Center, 2215 Fuller Road, Ann Arbor, \\ Michigan 48105
}

\begin{abstract}
Decreased responsiveness of the aged to infection may be associated with a decline in monokine production. Prior studies in macrophages have used different eliciting agents, and results have varied. We assessed the effect of age on interleukin-1 (IL1), tumor necrosis factor (TNF), and interleukin-6 (IL-6) in unelicited, thioglycollate (TG)-elicited, and complete Freund's adjuvant (CFA)-elicited peritoneal macrophages. Resident macrophages or CFA-elicited macrophages from middle aged or aged mice produced significantly less monokine bioactivity than resident or CFA-elicited macrophages from young mice. Monokine bioactivity from TG-elicited macrophages from aged and middle aged mice was significantly increased when compared with macrophages of young mice. Eliciting agents may alter macrophage populations and interactions with other cells leading to changes in monokine bioactivity with aging.
\end{abstract}

Key Words: interleukin-1, interleukin-6, tumor necrosis factor, complete Freund's adjuvant, thioglycollate, age

\section{INTRODUCTION}

THE DIMINISHED response of the aged host to infection has been well described. A decline in the febrile response, trace metal responses, and diminished clearance of organisms with increasing age has been noted. In particular, the aged have difficulty in containing intracellular pathogens (Gardner and Remington, 1977; Emmerling et al., 1979; Louria et al., 1982). The monocyte-macrophage system plays a critical role in the acute phase response and containment of pathogens. Despite the inability of the aged host to respond to infection, few clear-cut defects in in-vitro monocyte-macrophage function have been found (Perkins, 1971; Johnson et al., 1978; Gardner et al., 1981; Caperna and Garvey, 1982; Finger et al., 1982; Wustrow et al., 1982; Antonaci et al., 1984; Petrequin and Johnson, 1984; Esposito et al., 1988; Lavie and Gershon, 1988; Chen et al., 1991). A diminished ability to produce the monokines/endogenous pyrogens, IL-1 and TNF, in the aged has

Correspondence to: S.F. Bradley.

(Received 13 April 1992; Accepted 23 June 1992) 
been described by some investigators using febrile response assays (Norman et al., 1988), bioactivity assays (Bruley-Rosset and Vergnon, 1984; Hayari et al., 1984; Inamizu et al., 1985; Bessler et al., 1989; Bradley et al., 1989; Rudd and Banerjee, 1989; Davila et al., 1990) and enzyme-linked immunosorbent assay (ELISA) methods (Mooradian et al., 1991); however, others have not found these defects (Rosenberg et al., 1983; Jones et al., 1984; Kauffman, 1986; Amadori et al., 1988; Bradley et al., 1990; Putnam and Peterson, 1991).

This variation in experiments assessing monokine production by the aged might relate to differences in technique, especially methods to obtain macrophages. Different agents used to elicit peritoneal macrophages for study have been shown to alter macrophage function (Edelson et al., 1975; Johnston et al., 1978; North, 1978; Ruco and Meltzer, 1978; Hopper and Geczy, 1980; Ogmundsdottir, 1980; Spitalny, 1981; Rasmussen et al., 1983; Leijh et al., 1984; Blanckmeister and Sussdorf, 1985; Hopper, 1986; Tannenbaum et al., 1987; Melnicoff et al., 1989; Higuchi et al., 1990; Reed and Burnham, 1991; Tomioka and Saito, 1992) and possibly monokine production (Marcinkiewicz, 1991) through mechanisms that are not yet well defined. In this study, the effects of various eliciting agents, complete Freund's adjuvant (CFA), thioglycollate (TG), or no treatment, on IL-1, IL-6, and TNF bioactivity in peritoneal macrophage supernatants from young, middle aged, and aged mice was assessed.

\section{MATERIALS AND METHODS}

\section{Mice}

Young (2-3 months), middle aged (12-13 months), and aged (23-25 months) C57BL/ 6 male mice were obtained from the University of Michigan Core Facility for Aged Rodents or from the National Institute on Aging. Animals were housed at $26^{\circ} \mathrm{C}$, and given chow and water ad libitum. Macrophages were not used in the study if the donor mice appeared ill or gross anatomic abnormalities were noted at the time of harvest of peritoneal exudate cells.

\section{Macrophage isolation and culture}

Mice in each age group were injected intraperitoneally with $3 \mathrm{ml}$ of $3 \%$ TG (Difco, Detroit), $0.5 \mathrm{ml}$ CFA (Difco) that had been emulsified 1:1 in pyrogen-free saline, or received no injection of an eliciting agent (resident macrophages). Peritoneal exudate cells were harvested 4 days following injection of TG and 14 days following injection of CFA by washing the abdominal cavity with $6 \mathrm{ml}$ Hanks' balanced salt solution (HBSS) (JRH Biologicals, Lenexa, KS).

The cells were washed, counted, and the percentage of cells which were macrophages was assessed morphologically and with nonspecific esterase stain (Sigma, St. Louis). A final concentration of $2 \times 10^{6}$ cells $/ \mathrm{ml}$ was added to RPMI 1640 medium containing $2 \mathrm{mM} \mathrm{L}$ glutamine, $5 \mathrm{u} / \mathrm{ml}$ penicillin, and $5 \mu \mathrm{g} / \mathrm{ml}$ streptomycin (JRH Biologicals). One $\mathrm{ml}$ of cell suspension was added to each well of a 24-well flat-bottomed plastic plate (Flow Laboratories, McLean, VA), and plates were incubated at $37^{\circ} \mathrm{C}$ in $5 \% \mathrm{CO}_{2}$.

After $1 \mathrm{~h}$, the nonadherent cells were removed by two vigorous washings with HBSS. For each mouse, adherent cells from one well were removed with a rubber policeman and 
counted. The adherent cells in the remaining wells were incubated in the above medium with $10 \mu \mathrm{g} / \mathrm{ml}$ Escherichia coli 0111:B4 lipopolysaccharide (LPS) (Difco). Supernatants were collected from different wells at 1 or $2,4,8,24$, and $48 \mathrm{~h}$ following LPS stimulation, centrifuged to remove cellular debris, and stored at $-70^{\circ} \mathrm{C}$ prior to assay for monokines.

\section{Monokine bioassays}

TNF- $\alpha$ concentrations in the supernatants were determined by a modified cytotoxicity assay using the WEHI 164 subclone 13 murine fibrosarcoma cell line (gift of Dr. Steven Kunkel) (Espevik and Nissen-Meyer, 1986). Serial 1:2 dilutions of supernatants or human recombinant TNF $\alpha$ (rhTNF) Genzyme, Boston, MA) were made in complete medium containing RPMI- $1640,2 \mathrm{mM}$ L-glutamine, $5 \mathrm{u} / \mathrm{ml}$ penicillin, $5 \mu \mathrm{g} / \mathrm{ml}$ streptomycin, and $10 \%$ heat-inactivated mycoplasma-free fetal calf serum (JRH Biologicals). A dilution of supernatant or standard was added in triplicate in 100- $\mu$ aliquots to each well of a 96-well flat bottom culture plate (Flow Laboratories). WEHI cells were adjusted to a concentration of $5 \times 10^{5}$ cells $/ \mathrm{ml}$ in complete media, and $100-\mu l$ aliquots were added to the wells which contained either supernatants or standards. The plates were incubated for $18 \mathrm{~h}$ at $37^{\circ} \mathrm{C}$ in $5 \% \mathrm{CO}_{2}$.

IL-1 concentrations in the supernatants were determined by a proliferation assay using the D10.G4.1 T helper cell line (ATCC \#TIB224, Rockville, MD) (Kaye et al., 1983). Serial 1:3 dilutions of supernatants or human concensus IL-1 (hIL-1) (Endogen, Boston) were made in complete medium containing Click's medium (Irvine Scientific, Santa Ana, CA), $2.5 \mu \mathrm{g} / \mathrm{ml}$ concanavalin A (Pharmacia, Piscataway, NJ), 10\% fetal calf serum, $2 \mathrm{mM}$ 2-mercaptoethanol, $2 \mathrm{mM}$ L-glutamine, $5 \mathrm{u} / \mathrm{ml}$ penicillin, and $5 \mu \mathrm{g} / \mathrm{ml}$ streptomycin. One-hundred-microliter aliquots of each supernatant or standard dilution were added in triplicate to each well of a 96-well flat-bottomed plate. D10.G4.1 cells were adjusted to a concentration of $2 \times 10^{5}$ cells $/ \mathrm{ml}$ in complete media, and $100-\mu l$ aliquots were added to the wells which contained either the supernatants or standards. The plates were incubated for $48 \mathrm{~h}$ at $37^{\circ} \mathrm{C}$ in $5 \% \mathrm{CO}_{2}$.

IL- 6 concentrations in the supernatants were determined by a proliferation assay using the IL-6-dependent B9 hybridoma cell line (gift of Drs. L.A. Aarden and M.J. Kluger) (Helle et al., 1988). Serial 1:3 dilutions of supernatants or human recombinant IL-6 (rhIL6) (Genzyme, Boston, MA) were made in $0.2 \mathrm{ml}$ of Iscove's modified Dulbecco's medium (Gibco, Grand Island, NY) containing 10\% fetal calf serum, 2 mM 2-mercaptoethanol, 5 $\mathrm{u} / \mathrm{ml}$ pencillin, and $5 \mu \mathrm{g} / \mathrm{ml}$ streptomycin. One-hundred-microliter aliquots of each supernatant or standard dilution were added in triplicate to each well of a 96-well flat-bottomed plate. The B9 cells were adjusted to $5 \times 10^{4} \mathrm{cells} / \mathrm{ml}$ in complete media, and $100-\mu \mathrm{l}$ aliquots were added in triplicate to each well containing either supernatants or rhIL-6. The cells were incubated for $72 \mathrm{~h}$ at $37^{\circ} \mathrm{C}$ in $5 \% \mathrm{CO}_{2}$.

\section{${ }^{3} H$-thymidine incorporation}

Monokine proliferative and cytotoxic activities were measured by ${ }^{3} \mathrm{H}$-thymidine incorporation. ${ }^{3} \mathrm{H}$-thymidine (ICN, Costa Mesa, CA) $(1 \mu \mathrm{Ci})$ was added to all wells. IL-1 and TNF assay plates were incubated for $8 \mathrm{~h}$ and IL-6 assay plates were incubated for $4 \mathrm{~h}$ at $37^{\circ} \mathrm{C}$ in $5 \% \mathrm{CO}_{2}$. The cells were harvested and thymidine incorporation was measured in a beta counter. 


\section{Calculation of monokine concentrations}

Standard curves were drawn by comparing dpm (y axis) versus the log of known concentrations of rhIL-1 or rhTNF ( $\mathrm{x}$ axis) for each experiment. The linear equation that described the straight portion of the recombinant standard curve was obtained using a computer graphics program (Cricket Software, Malvern, PA). The dpm measured for each supernatant dilution $(y)$ was used in the equation to calculate the concentration of murine monokine $(x)$ present in the dilute supernatant. The limits of detection were $15 \mathrm{pg} / \mathrm{ml}$ for TNF and $0.1 \mathrm{pg} / \mathrm{ml}$ for IL- $\mathrm{l}$ in our assays.

To assess IL-6 activity, a separate curve was drawn for each mouse (dpm $[y]$ vs. supernatant dilution $[x]$ ). One half of the maximum proliferative response (defined as 1 unit of IL-6 activity) was calculated from each curve for each mouse. An equation ( $y=m x+\mathrm{b})$ was derived by linear regression analysis to define the straight portion of each curve. The $\mathrm{dpm}$ for each mouse half-maximal response $(y)$ was used in each equation to calculate the dilution of supernatant $(x)$ that contained 1 unit of IL- 6 activity for each mouse. The reciprocal of that dilution represented the number of units of IL- 6 in the undiluted supernatant.

A standard curve for rhIL-6 was also drawn (dpm vs. concentration $[\mathrm{pg} / \mathrm{ml}]$ ) for each experiment. The concentration of rhIL- 6 resulting in one-half maximal proliferation was calculated. A unit of IL- 6 activity for each mouse could then be compared against a unit of rhIL-6 activity of known concentration. By converting the murine IL- 6 units to equivalent units of rhIL-6, a final concentration in $\mathrm{pg} / \mathrm{ml}$ could be calculated for each murine supernatant. We found that $1 \mathrm{u} / \mathrm{ml}$ of murine IL-6 activity in our assay generally corresponded to $2 \mathrm{u} / \mathrm{ml}$ or $200 \mathrm{pg} / \mathrm{ml}$ of rIL-6. The limit of detection of rhIL-6 was $50 \mathrm{pg} / \mathrm{ml}$ in our assay.

\section{Assay controls}

Proliferation or cytotoxicity was assessed using complete medium alone or cell lines in complete medium as a control to assure that nonspecific activation had not occurred. In addition, in each experiment, triplicate wells were set up with supernatants from macrophages which had not been stimulated with LPS. Antibodies for each murine monokine (Genzyme) were used in their respective assays to ascertain that the proliferative or cytotoxic response was specific for that monokine. Polyclonal rabbit antimurine TNF $\alpha(1: 10)$ was added to 5 different murine supernatants, polyclonal rabbit antimurine IL-1 (1:10) was added to supernatants from 2 different mice, and monoclonal rat antimurine IL-6 (1:50) was added to supernatants from 3 different mice, each time using the appropriate specific cell line.

\section{Monokine ELISA methods}

CFA-elicited macrophage supernatants, from young, middle aged, and aged mice, were tested by ELISA for the three monokines. Supernatants from macrophages that had been incubated with LPS for $24 \mathrm{~h}$ were selected for TNF measurement, 8-h supernatants were used for IL-1 measurement, and 4-h supernatants for IL-6 measurement. Undiluted supernatants and supernatants diluted severalfold in RPMI were assayed in duplicate in an ELISA for murine TNF $\alpha$ (Genzyme, Boston), IL- $1 \alpha$, and IL-6 (Endogen, Boston). Limits of detection were $50 \mathrm{pg} / \mathrm{ml}$ for $\mathrm{TNF} \alpha$ and $15 \mathrm{pg} / \mathrm{ml}$ for $\mathrm{IL}-1 \alpha$ and IL-6. 
Statistical analysis

The effect of age on the bioactivity of each monokine and cell yields was determined by one-way analysis of variance.

\section{RESULTS}

\section{Monokine bioactivity in CFA-elicited macrophages}

While TNF bioactivity was detectable at $2 \mathrm{~h}$ (data not shown), the highest levels were found at $4 \mathrm{~h}$, with a rapid decline thereafter in supernatants from all age groups (Fig. 1A). Supernatants from aged and middle aged mice consistently contained less TNF than supernatants from young mice at all time-points; these results were significant at 8, 24, and $48 \mathrm{~h}$.

For IL- 1 in all age groups, supernatant bioactivity was barely detectable at $1 \mathrm{~h}$ (data not known), and readily measured at 4 and $8 \mathrm{~h}$, with the peak response at $24 \mathrm{~h}$, followed by a decline at $48 \mathrm{~h}$ (Figure 1B). Supernatants from aged and middle aged mice showed significantly less IL- 1 activity at 8 and $24 \mathrm{~h}$ than supernatants from young mice.

IL-6 activity was detectable at $1 \mathrm{~h}$ (data not shown), and showed only modest rises through $48 \mathrm{~h}$. Supernatants from aged mice contained significantly less IL-6 activity than supernatants from middle aged and young mice at $4 \mathrm{~h}$ (Fig. 1C). After that, no significant age-related differences were apparent.

\section{Monokine bioactivity in TG-elicited macrophages}

Major differences were apparent when monokine bioactivity was assessed in supernatants from TG-elicited macrophages. Increasing age did not decrease monokine bioactivity, as seen with CFA-elicited macrophages. In fact, at many time-points supernatants from TG-elicited aging macrophages showed more monokine bioactivity than those from young mice.

Although TNF bioactivity was detectable at $2 \mathrm{~h}$ (data not shown), peak TNF levels were not found at $4 \mathrm{~h}$ (as noted with CFA-elicited cells), but at 8 and $24 \mathrm{~h}$ (Fig. 2A). In contrast to CFA results, supernatants from TG-elicited macrophages from aged and middle aged mice contained more activity than supernatants from young mice at 4,8 , and $24 \mathrm{~h}$.

In TG-elicited macrophage supernatants, IL-1 activity was very low when compared to levels noted in supernatants from macrophages elicited with CFA (note change in scale of the graph), and peak levels were found at $48 \mathrm{~h}$ (Fig. 2B). Macrophages of aged mice produced more IL-1 than macrophages of young and middle aged mice, with a significant effect of increasing age noted at all time-points.

IL-6 bioactivity was significantly greater than TNF and IL-1 in TG-elicited macrophage supernatants, and greater than that noted in CFA-elicited macrophages. IL-6 was detectable at $2 \mathrm{~h}$ (data not shown), and peak IL-6 levels were observed at 24 and $48 \mathrm{~h}$ (Fig. 2C). At 8,24 , and $48 \mathrm{~h}$, supernatants of macrophages from aged and middle aged mice contained more IL- 6 than supernatants from young mice, but a statistically significant effect of age was found only at $8 \mathrm{~h}$.

\section{Monokine bioactivity in resident macrophages}

In general, results with resident peritoneal macrophages mirrored those found with CFA-elicited macrophages. However, far less TNF was produced by the resident macrophages than those elicited with CFA or TG (note difference in scale of the graph) (Fig. 3A). 


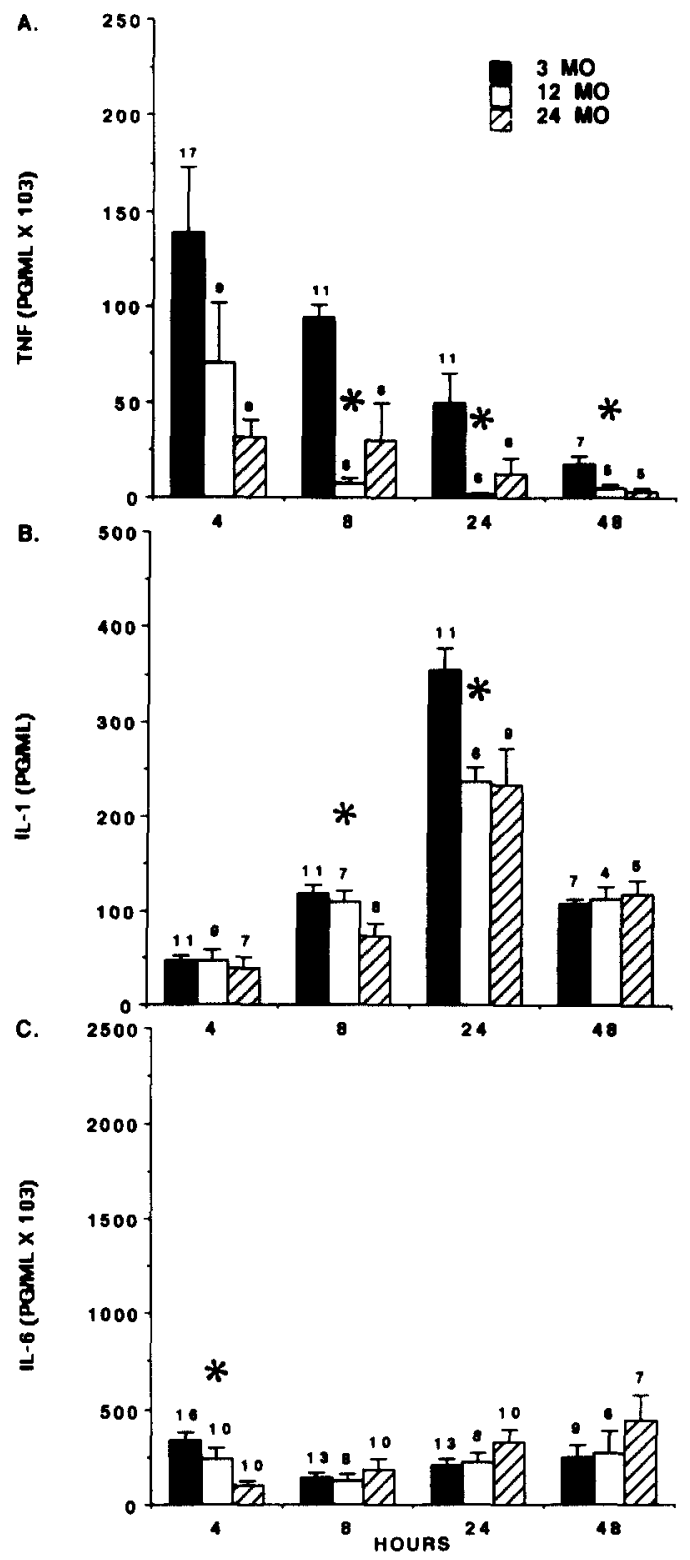

FIG. 1. Monokine bioactivity in supernatants from CFA-elicited peritoneal macrophages from three age groups of mice stimulated with LPS in vitro. All data are expressed as mean \pm SE. Statistical differences were assessed by one-way analysis of variance. ${ }^{*}=$ significant time-point. (A) TNF: Supernatants from aged and middle aged macrophages contained significantly less TNF activity than supernatants from young macrophages at $8 \mathrm{~h}(p=0.0001), 24 \mathrm{~h}(p=0.028)$, and $48 \mathrm{~h}(p=0.013)$. (B) IL-1: Supernatants from aged macrophages contained significantly less IL-1 activity than supernatants from middle aged and young macrophages at $8 \mathrm{~h}(p=$ $0.023)$ and $24 \mathrm{~h}(p=0.008)$. (C) IL-6: Supernatants from aged and middle-aged macrophages contained significantly less IL- 6 activity than supernatants from young macrophages at $4 \mathrm{~h}(p$ $=0.002$ ). 


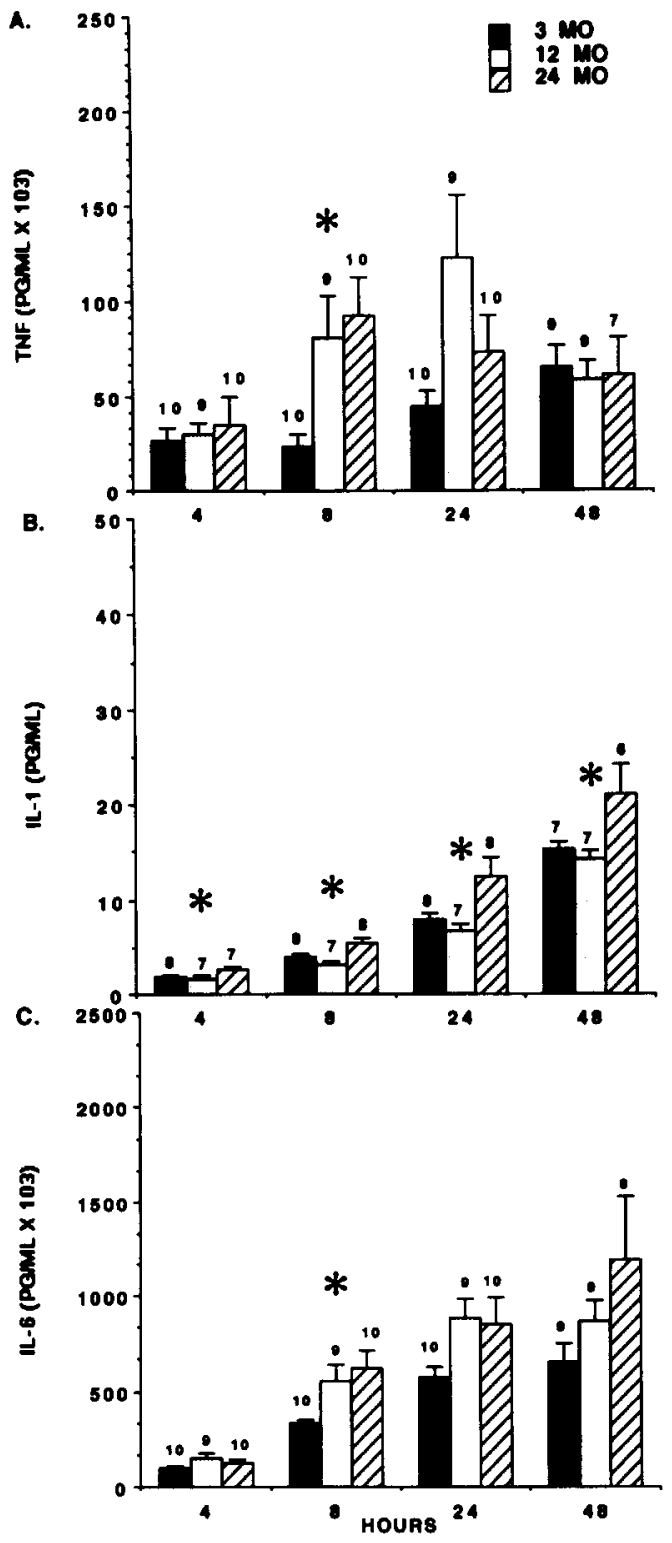

FIG. 2. Monokine bioactivity in supernatants from TG-elicited peritoneal macrophages from three age groups of mice stimulated with LPS in vitro. All data are expressed as the mean \pm SE. Statistical differences were assessed by one-way analysis of variance. ${ }^{*}=$ significant timepoint. (A) TNF: Supernatants from aged and middle aged macrophages contained significantly more TNF activity than supernatants from young macrophages at $8 \mathrm{~h}(p=0.033)$. (B) IL-1: Supernatants from aged macrophages contained significantly more IL-1 activity than supernatants from middle aged and young macrophages at $4 \mathrm{~h}(p=0.05), 8 \mathrm{~h}(p=0.005), 24 \mathrm{~h}(p$ $=0.011)$, and $48 \mathrm{~h}(p=0.039)$. (C) IL-6: Supernatants from aged and middle aged macrophages contained significantly more IL- 6 activity than supernatants from young macrophages at $8 \mathrm{~h}(p=0.02)$. 


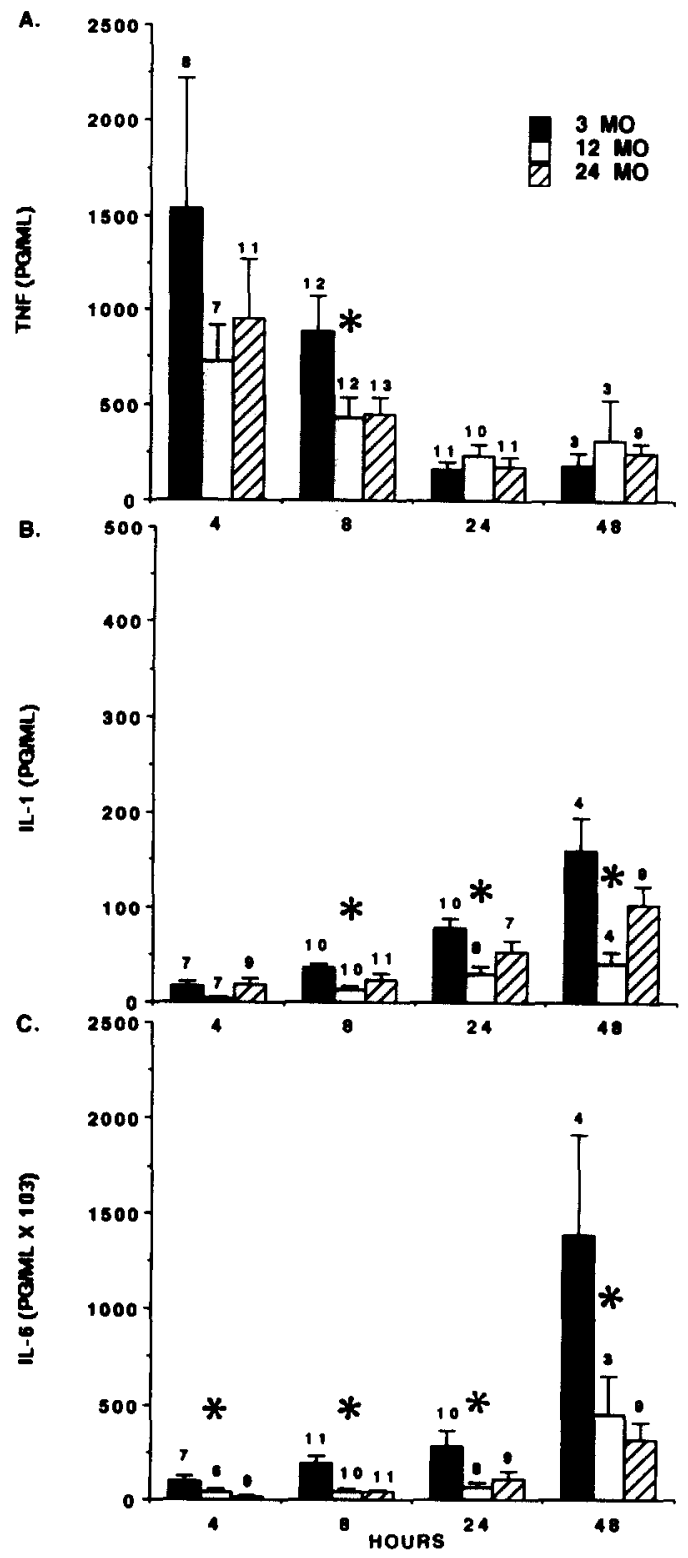

Fig. 3. Monokine bioactivity in supernatants from resident peritoneal macrophages from three age groups of mice stimulated with LPS in vitro. All data are expressed as the mean \pm SE. Statistical differences were assessed by one-way analysis of variance. ${ }^{*}=$ significant time-point. (A) TNF: Supernatants from aged and middle aged macrophages contained significantly less activity than supernatants from young macrophages at $8 \mathrm{~h}(p=0.043)$. (B) lL-1: Supernatants from aged and middle aged macrophages contained significantly less activity than supernatants from young macrophages at $8 \mathrm{~h}(p=0.007), 24 \mathrm{~h}(p=0.004)$, and $48 \mathrm{~h}(p=0.031)$. (C) IL-6: Supernatants from aged and middle aged macrophages contained significantly less activity than supernatants from young macrophages at $4 \mathrm{~h}(p=0.008), 8 \mathrm{~h}(p=0.0001), 24 \mathrm{~h}(p=0.035)$, and $48(p=0.024)$. 
As noted with CFA-elicited macrophages, peak TNF levels were detected at $4 \mathrm{~h}$. Supernatants from resident macrophages of aged and middle aged mice contained less TNF than supernatants from macrophages of young mice, but significant differences were seen only at $8 \mathrm{~h}$.

IL-1 bioactivity in supernatants from resident macrophages was almost as great as that seen in CFA-elicited macrophages, and much greater than that seen in thioglycollate-elicited macrophages (Fig. 3B). IL-1 levels peaked at the same time as IL-1 levels from TGelicited macrophages ( $48 \mathrm{~h}$ ) and later than IL-1 levels from CFA-elicited macrophages ( 24 h). Supernatants from resident macrophages of aged and middle aged mice contained less IL-1 than supernatants from macrophages of young mice, and a significant effect of age was found at 8,24 , and $48 \mathrm{~h}$.

Levels of IL- 6 detected in resident macrophage supernatants were similar to levels detected in CFA-elicited and TG-elicited supernatants. Peak IL-6 bioactivity was detected at $24 \mathrm{~h}$, as noted in TG-elicited macrophages (Fig. 3C). Supernatants from resident macrophages of aged and middle aged mice contained significantly less IL- 6 bioactivity when compared with supernatants from macrophages of young mice at $4,8,24$, and $48 \mathrm{~h}$.

\section{Assay controls}

Supernatants from macrophages cultured in medium without LPS produced no measureable monokines. When ${ }^{3} \mathrm{H}$-thymidine was added to complete medium alone, or WEHI, D10.G4.1 cells, and B9 cells in their respective complete media, only minimal cytoxicity (WEHI cells) or proliferation (D10.G4.1 and B9 cells) was noted, showing no nonspecific activation by medium or cells alone (Fig. 4). Addition of rhTNF to WEHI cells resulted in a marked decline in ${ }^{3} \mathrm{H}$-thymidine incorporation, showing increased cytotoxicity. In contrast, addition of hIL-1 to D10.G4.1 cells or rhIL-6 to B9 cells resulted in marked incorporation of ${ }^{3} \mathrm{H}$-thymidine, reflecting increased proliferation. The murine supernatants tested in these experiments showed activity similar to the standards in all three assays.

Addition of antimurine TNF $\alpha$ to murine supernatants abolished cytotoxic activity in the WEHI assay by $85 \%$. Addition of antimurine IL-1 to murine supernatants abolished proliferative activity in the D10.G4.1 assay by $96 \%$. Addition of antimurine IL-6 to murine supernatants abolished proliferative activity in the B9 assay by $97 \%$.

\section{Measurement of monokines by ELISA}

While monokine bioactivity was significantly reduced with aging at various time-points, measurement of IL- $1 \alpha$, TNF $\alpha$, and IL- 6 in the same CFA-elicited macrophage supernatants by ELISA revealed no significant differences (Table 1). However, we did find a trend toward decreasing levels of all three monokines with increasing age. Overall, monokine levels as measured by ELISA were markedly lower than TNF $\alpha$, IL-1, and IL-6 levels measured by bioactivity assays at 24,8 , and $4 \mathrm{~h}$, respectively.

\section{Effect of aging and eliciting agents on adherent cell numbers}

Numbers of peritoneal exudate cells obtained following elicitation with either CFA or TG did not differ significantly among the three age groups (Table 2). In contrast, nonelicited resident peritoneal exudate cell yields were significantly greater from aged mice when compared with cell yields from young and middle aged mice. The percentage of cells which 


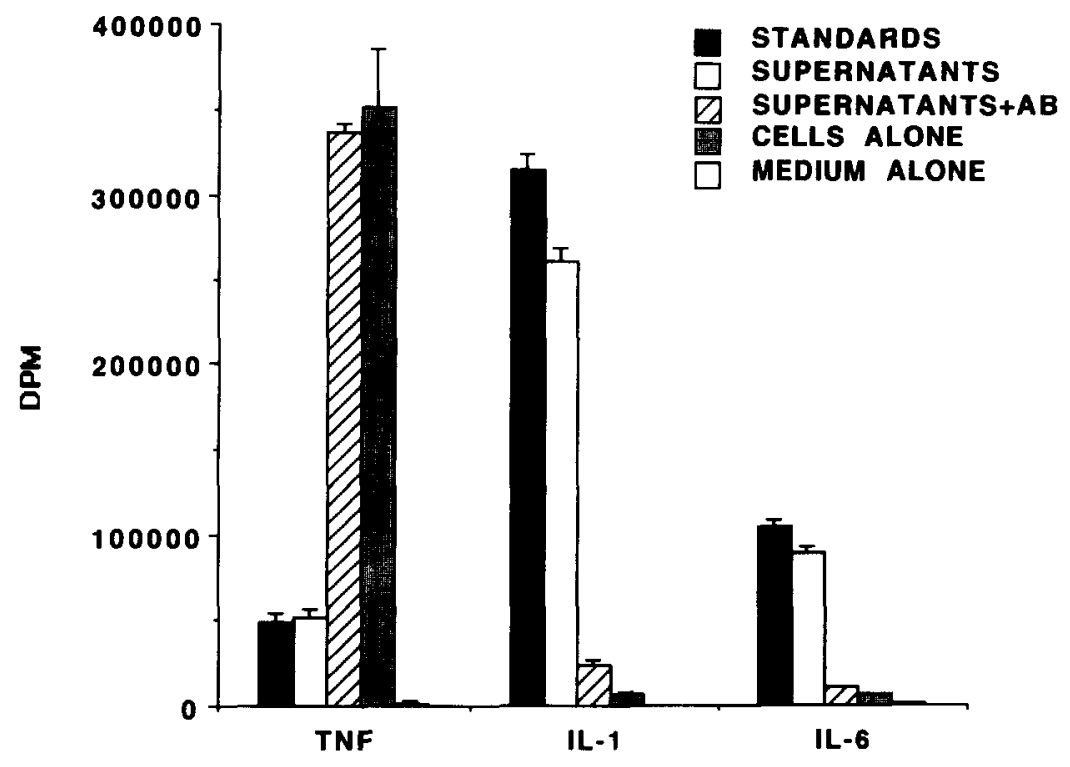

FIG. 4. Results of blocking and assay control experiments. Complete medium and WEHI 164 subclone 13 cells, DI0.G4.1 cells, and B9 cells in complete medium were run as negative controls in all respective bioassays for TNF, IL-1, and IL-6. Standards used were recombinant human TNF $\alpha$, concensus human IL-1, and recombinant human IL-6; activity was similar to that of the murine supernatants tested. Blocking experiments were done with antimurine TNF $\alpha$ mixed with supernatants from 5 different mice, antimurine IL- 1 mixed with supernatants from 2 different mice, and antimurine IL- 6 mixed with supernatants from 3 different mice. Data are expressed as the mean $\pm \mathrm{SE}$.

were macrophages, identified by morphology and staining with nonspecific esterase, did not differ significantly with age in exudates elicited with CFA or TG. However, the percentage of cells which were macrophages was significantly higher in young mice when nonelicited resident peritoneal macrophages were enumerated. The total number of cells which adhered to tissue culture plates were similar in all age groups, regardless of whether they were elicited with CFA or TG or were nonelicited resident cells. The percent of adherent cells that were esterase positive was greater than $95 \%$, regardless of age or whether the cells were elicited with TG or CFA or were resident cells.

TABLE 1. CONCENTRATIONS OF MONOKINES IN SUPERNATANTS FROM CFA-ELICITED MACROPHAGES MEASURED BY ELISA

\begin{tabular}{|c|c|c|c|c|c|c|}
\hline \multirow[b]{2}{*}{ Age grotup } & \multicolumn{2}{|c|}{$T N F_{\alpha}$} & \multicolumn{2}{|c|}{$I L-1 \alpha$} & \multicolumn{2}{|c|}{$I L-6$} \\
\hline & $(\mathrm{N})$ & $(p g / m l)$ & $(\mathrm{N})$ & $(p g / m l)$ & $(\mathrm{N})$ & $(p g / m l)$ \\
\hline Young & (8) & $3250 \pm 462$ & (8) & $120 \pm 24$ & (9) & $1272 \pm 325$ \\
\hline Middle & (7) & $2907 \pm 269$ & (7) & $91 \pm 8$ & (5) & $893 \pm 422$ \\
\hline Aged & (8) & $2629 \pm 627$ & (9) & $69 \pm 19$ & (8) & $570 \pm 148$ \\
\hline
\end{tabular}

Supernatants from CFA-elicited macrophages were incubated with LPS $10 \mu \mathrm{g} / \mathrm{ml}$ for $4 \mathrm{~h}$ (IL-6), $8 \mathrm{~h}$ (IL-1 $\alpha$ ), and $24 \mathrm{~h}(\mathrm{TNF} \alpha)$. All data are expressed as mean \pm SE. Differences among age groups for each monokine were assessed by one-way analysis of variance, and no significant differences were found. 
TABLE 2. TOTAL YIELD OF ELICITED AND RESIDENT PERITONEAL CELLS, PERCENT MACROPHAGES, AND ADHERENT CELL NUMBERS FROM THREE AGE GROUPS OF MICE

\begin{tabular}{llllllll}
\hline Cells $^{a}$ & Age & TG & (N) & CFA & (N) & Resident & (N) \\
\hline \multirow{4}{*}{ Total yield $\left(10^{6}\right)$} & Young & $45 \pm 4$ & $(18)$ & $54 \pm 6$ & $(9)$ & $2 \pm 0.2$ & $(12)$ \\
& Middle & $54 \pm 6$ & $(15)$ & $50 \pm 6$ & $(7)$ & $5 \pm 1.1$ & $(11)$ \\
& Aged & $52 \pm 8$ & $(15)$ & $67 \pm 12$ & $(7)$ & $12 \pm 2.0$ & $(11)^{*}$ \\
& Young & $93 \pm 1$ & $(8)$ & $89 \pm 3$ & $(4)$ & $72 \pm 3$ & $(20)^{* *}$ \\
Macrophages (\%) & Middle & $89 \pm 2$ & $(6)$ & $91 \pm 1$ & $(5)$ & $49 \pm 5$ & $(9)$ \\
& Aged & $96 \pm 3$ & $(4)$ & $88 \pm 1$ & $(6)$ & $54 \pm 7$ & $(8)$ \\
& Young & $0.8 \pm 0.04$ & $(8)$ & $0.9 \pm 0.1$ & $(9)$ & $0.9 \pm 0.1$ & $(11)$ \\
Adherent cells $\left(10^{6}\right)$ & Middle & $0.7 \pm 0.05$ & $(6)$ & $1.0 \pm 0.1$ & $(7)$ & $1.3 \pm 0.1$ & $(11)$ \\
& Aged & $0.9 \pm 0.05$ & $(4)$ & $0.9 \pm 0.1$ & $(7)$ & $1.3 \pm 0.1$ & $(11)$ \\
\hline
\end{tabular}

${ }^{a}$ Each data point represents the mean $\pm S E$.

*Aged mice yielded more resident cells than young or middle aged mice, $p=0.0001$ by one-way analysis of variance. ${ }^{* *}$ Young mice yielded a greater proportion of macrophages than aged or young mice, $p=0.001$ by one-way analysis of variance.

\section{DISCUSSION}

Various approaches to assess the effect of aging on the monocyte-macrophage system have been used. Early studies of monocyte-macrophage function focused on the pyrogenic properties of the monokines (Kauffman, 1986; Norman et al., 1988). Supernatants from shellfish glycogen-elicited rat peritoneal macrophages showed no decline in pyrogenic activity with increasing age (Kauffman, 1986). In contrast, a significant decline in the pyrogenic activity of supernatants was found with increasing age when murine adherent peritoneal cells were elicited with thioglycollate (Norman et al., 1988).

Subsequent approaches to assess the effects of aging on monokines involved measuring their proliferative or cytotoxic effects on various cell lines. Inamizu et al., using supernatants from LPS-elicited, adherent mouse peritoneal cells, showed a significant reduction in IL-1 mediated thymocyte proliferation with increasing age (1985). Bruley-Rosset and Vergnon found similar results using supernatants from resident nonelicited adherent murine peritoneal cells in a thymocyte proliferation assay (1984).

However, no significant differences were found when supernatants from nonelicited resident adherent rat peritoneal macrophages were assessed for IL-1 bioactivity in a thymocyte proliferation assay (Rosenberg et al., 1983). In contrast, we found a decline in IL-1 and TNF bioactivity, by thymocyte proliferation and L929 cytotoxicity assays, respectively, in supernatants from shellfish glycogen-elicited rat peritoneal macrophages (Bradley et al., 1989). These studies were corroborated by Davila et al., who found a decline in TNF bioactivity by the WEHI assay in supernatants from aged rat resident peritoneal macrophages (1990).

In the above studies, investigators used various animal models and different methods of obtaining and stimulating macrophages. In our current study, we found that the eliciting agents used greatly influenced the occurrence of age-related differences in monokine bioactivity. Our results with nonelicited resident macrophages confirm similar studies with resident macrophages by Bruley-Rosset and Vergnon showing that IL-1 bioactivity is reduced in supernatants from aged mice (1984), and support findings by Davila et al. that TNF bioactivity is reduced in supernatants from aged rats (1990). 
Monokine production in aged TG-elicited peritoneal macrophages contrasted greatly with the findings using nonelicited resident macrophages and CFA-elicited macrophages, and with prior studies of LPS-elicited (Inamizu et al., 1985) and shellfish glycogen-elicited macrophages (Bradley et al., 1989). When macrophages were elicited with TG, no apparent defect in monokine bioactivity was seen with aging; whereas aged macrophages elicited with LPS, glycogen, and CFA all showed a decline in monokine bioactivity (Inamizu et al., 1985; Bradley et al., 1989).

It is likely that the use of either resident or elicited peritoneal cells can greatly influence the outcome of experiments in aging, macrophage function, and cytokine production. Peritoneal macrophages elicited with TG have been found to have increased pinocytotic and recruitment rates, differences in protein synthesis patterns, and increased tumoricidal activity, when compared with proteose peptone-elicited macrophages (Edelson et al., 1975; Hopper, 1986; Tannenbaum et al., 1987; Higuchi et al., 1990). Thioglycollate has also been associated with a depressive effect on microbicidal capacity (Spitalny, 1981; Leijh et al., 1984). Direct comparisons of the effects of various eliciting agents (i.e., "stimulants or irritants" or activating agents) on monokine production in aging animals have not been carried out previously.

Differences in monokine bioactivity seen with CFA and TG might be explained on the basis of differences in the functional state of the macrophages elicited or heterogeneity of the populations elicited (Melnicoff et al., 1989; Reed and Burnham, 1991). Interactions of these macrophages with other types of cells and cytokines in vivo also could alter monokine production in vitro. Differences in monokine production, seen with the use of different eliciting agents to obtain macrophages, might be explained by the induction of substances which alter macrophage function, such as prostaglandin $\mathrm{E}_{2}$ (Goodwin and Messner, 1979) or other cytokines, such as interferon- $\gamma$ (Collart et al., 1986) interleukin4 (Essner et al., 1989), interleukin-10 (De Waal et al., 1991), or granulocyte-macrophage colony stimulating factor (Heidenreich et al., 1989). Similar hypotheses have been raised by Marcinkiewicz, who found that supernatants from TG- or LPS-elicited murine macrophages yielded differences in IL-1, IL-6, and TNF bioactivity (Marcinkiewicz, 1991; Tachibana et al., 1992).

The function of aged macrophages has been assessed using primarily peritoneal macrophages (Perkins, 1971; Johnson et al., 1978; Finger, et al., 1982; Wustrow et al., 1982; Petrequin and Johnson, 1984; Lavie and Gershon, 1988; Chen et al., 1991) and only occasionally alveolar macrophages (Esposito et al., 1988) or Kupffer cells (Caperna and Garvey, 1982). These studies have been performed with peritoneal macrophages elicited by a wide variety of different agents. In only two studies was the function of elicited macrophages compared with the function of nonelicited resident macrophages (Lavie and Gershon, 1988; Chen et al., 1991). Although an age-related difference was seen in phagocytosis, superoxide generation, and microbicidal capacities in elicited macrophages, no agerelated decrease was noted when nonelicited resident macrophages were used (Lavie and Gershon, 1988; Chen et al., 1991).

We have also demonstrated that while monokine bioactivity was reduced with increasing age in supernatants from CFA-elicited cells, similar results were not found when the supernatants were assayed by ELISA methods. One possibility to explain these results is that IL-1, TNF, and IL-6 could have been produced in normal quantities, but inhibitors of IL-1 (Mazzei et al., 1990; Svenson et al., 1990), TNF (Seckinger et al., 1988; Peetre et 
al., 1988), and IL-6 (Novick et al., 1989) have been described. Future experiments will have to address whether any of these inhibitors of cytokine activity are increased with aging.

Our studies suggest that the regulation of monokine secretion may be altered, but not necessarily defective in the aged. This concept echoes that of Russo et al., who propose that aging does not cause clear-cut deficits in specific immune system function, but rather immune dysregulation leading to inappropriate responses by the aged host (1990). Our model may be useful in further studies of how aging alters homeostatic mechanisms which control monokine production.

Acknowledgments - This work was supported by the National Institutes of Health (AG08808) and the Research Service, Department of Veterans Affairs. We wish to thank Dr. Carol A. Kauffman for her advice in the preparation of the manuscript. We also wish to thank Dr. Arthur Johnson for his advice and assistance in the development of our assays for IL-1.

\section{REFERENCES}

AMADORI, A., ZANOVELlO, P., COZZI, E., CIMINALE, V., BORGHESAN, F., FAGIOLO, U., and CREPALDI, G. Study of some early immunological parameters in aging humans. Gerontology 34, 277-283, 1988.

ANTONACI, S., JIRILLO, E., VENTURA, M.T., GAROFALO, A.R., and BONOMO, L. Non-specific immunity in aging: Deficiency of monocyte and polymorphonuclear cell-mediated functions. Mech. Ageing Dev. 24, 367-375, 1984.

BESSLER, H., SIROTA, P., HART, J., and DJALDETTI, M. Lymphokine production in patients with Alzheimer's disease. Age Ageing 18, 21-25, 1989.

BLANCKMEISTER, C.A. and SUSSDORF, D.H. Macrophage activation by cross-linked dextran. J. Leukoc. Biol. 37, 209-219, 1985.

BRADLEY, S.F., VIBHAGOOL, A., KUNKEL, S.L., and KAUFFMAN, C.A. Monokine secretion in aging and protein malnutrition. J. Leukoc. Biol. 45, 510-514, 1989.

BRADLEY, S.F., VIBHAGOOL, A., FABRICK, S., TERPENNING, M.S., and KAUFFMAN, C.A. Monokine production by malnourished nursing home patients. Gerontology 36, 165-170, 1990.

BRULEY-ROSSET, M. and VERGNON, I. Interleukin-1 synthesis and activity in aged mice. Mech. Ageing Dev. 24, 247-264, 1984.

CAPERNA, T.J. and GARVEY, J.S. Antigen handling in aging: II. The role of Kupffer and endothelial cells in antigen processing in Fischer 344 rats. Mech. Ageing Dev. 20, 205-221, 1982.

CHEN, Y., SOLEM, L., and JOHNSON, A.G. Activation of macrophages from aging mice by detoxified lipid A. J. Leukoc. Biol. 49, 416-422, 1991.

COLLART, M.A., BELIN, D., VASSALLI, J.D., DeKOSSODO S., and VASALLI, P. $\gamma$ Interferon enhances macrophage transcription of the tumor necrosis factor/cachetin, interleukin-1, and urokinase genes, which are controlled by short-lived repressors. J. Exp. Med. 164, 2113-2118, 1986.

DAVILA, D.R., EDWARDS, C.K., ARKINS, S., SIMON, J., and KELLEY, K.W. Interferon- $\gamma$-induced priming for secretion of superoxide anion and tumor necrosis factor- $\alpha$ declines in macrophages from aged rats. FASEB J. 4, 2906-2911, 1990.

DE WAAL MALEFYT, R., ABRAMS, J., BENNETT, B., FIGDOR, C.G., and DE VRIES, J.E. Interleukin-10 (IL-10) inhibits cytokine synthesis by human monocytes: An autoregulatory role of IL-10 produced by monocytes. J. Exp. Med. 174, 1209-1220, 1991.

EDELSON, P.J., ZWIEBEL, R., and COHN, Z.A. The pinocytic rate of activated macrophages. J. Exp. Med. 142, 1150-1163, 1975.

EMMERLING, P., HOF, H., and FINGER, H. Age-related defense against infection with intracellular pathogens. Gerontology 25, 327-336, 1979.

ESPEVIK, T., and NISSEN-MEYER, J. A highly sensitive cell line, WEHI 164 clone 13, for measuring cytotoxic factor-tumor necrosis factor from human monocytes. J. Immunol. Methods 95, 99-105, 1986.

ESPOSITO, A.L., CLARK, C.A., and POIRER, W.J. An assessment of the respiratory burst and bactericidal activity of alveolar macrophages from adult and senescent mice. J. Leukoc. Biol. 43, 445-454, 1988. 
ESSNER, R., RHOADES, K., MCBRIDE, W.H., MORTON, D.L., and ECONOMOU, J.S. IL-4 down-regulates IL-1 and TNF gene expression in human monocytes. J. Immunol. 142, 3857-3861, 1989

FINGER, H., HEYMER, B., WIRSING VON KONIG, C.H., and EMMERLING, P. Macrophage function in senescence. Gerontology 28, 223-232, 1982.

GARDNER, I.D. and REMINGTON, J.S. Age-related decline in the resistance of mice to infection with intracellular pathogens. Infect. Immun. 16, 593-598, 1977.

GARDNER, I.D., LIM, L.T.K., and LAWTON, J.W.M. Monocyte function in ageing humans. Mech. Ageing Dev. 16, 233-239, 1981.

GOODWIN, J.S., and MESSNER, R.P. Sensitivity of lymphocytes to prostaglandin $E_{2}$ increases in subjects over age 70. J. Clin. Invest. 64, 434-439, 1979.

HAYARI, Y., KUKULANSKY, T., and GLOBERSON, A. Effects of in vivo indomethacin treatment in aging mice. Prostaglandins Leukot. Essent. Fatty Acids 15, 69-78, 1984.

HEIDENREICH, S., GONG, J.H., SCHMIDT, A., NAIN, M., and GEMSA, D. Macrophage activation by granulocyte-macrophage colony stimulating factor. J. Immunol. 143, 1198-1205, 1989.

HELLE, M., BOEIJE, L., and AARDEN, L.A. Functional discrimination between interleukin- 6 and interleukin1. Eur. J. Immunol. 18, 1535-1540, 1988.

HIGUCHI, M., HIGASHI, N., TAKI, H., and OSAWA, T. Cytolytic mechanisms of activated macrophages: Tumor necrosis factor and 1-arginine-dependent mechanisms act synergistically as the major cytolytic mechanisms of activated macrophages. J. Immunol. 144, 1425-1431, 1990.

HOPPER, K.E. Kinetics of macrophage recruitment and turnover in peritoneal inflammatory exudates induced by salmonella or thioglycollate broth. J. Leukoc. Biol. 39, 435-446, 1986.

HOPPER, K.E. and GECZY, C.L. Characterization of guinea pig macrophages: I. Mobility and maturation of peritoneal macrophages following inflammatory stimuli. Cell. Immunol. 56, 400-414, 1980.

INAMIZU, T., CHANG, M.P., and MAKINODAN, T. Influence of age on the production and regulation of interleukin-1 in mice. Immunology 55, 447-455, 1985.

JOHNSON, D.R., FERNANDES, G., and DOUGLAS, S.D. Age related decline in cytoplasmic spreading of mouse peritoneal macrophages. Dev. Comp. Immunol. 2, 347, 1978.

JOHNSTON, R.B., GODZIK, C.A., and COHN, Z.A. Increased superoxide anion production by immunologically activated and chemically-elicited macrophages. J. Exp. Med. 148, 115-127, 1978.

JONES, P.G., KAUFFMAN, C.A., BERGMAN, A.G., HAYES, C.M., KLUGER, M.J., and CANNON, J.G. Fever in the elderly: Production of leukocytic pyrogen by monocytes from elderly persons. Gerontology $\mathbf{3 0}$, 182-187, 1984.

KAUFFMAN, C.A. Endogenous pyrogen/interleukin-1 production in aged rats. Exp. Gerontol. 21, 75-78, 1986.

KAYE, J., PORCELLI, S., TITE, J., JONES, B., and JANEWAY, C.A. Both a monoclonal antibody and antisera specific for determinants unique to individual cloned helper $T$ cell lines can substitute for antigen and antigenpresenting cells in the activation of T cells. J. Exp. Med. 158, 836-856, 1983.

LAVIE, L. and GERSHON, D. Oxygen free radical production by mouse peritoneal macrophages as a function of age. Mech. Ageing Dev. 45, 177-189, 1988.

LEIJH, P.C.H., VAN ZWET, T.L., TER KUILE, M.N., and VAN FURTH, R. Effect of thioglycolate on phagocytic and microbicidal activities of peritoneal macrophages. Infect Immun. 46, 448-452, 1984.

LOURIA, D.B., PURNENDU, S., and BUSE, M. Age-dependent differences in outcome of infections, with special reference to experiments in mice. $J$. Am. Geriatr. Soc. 30, 769-773, 1982.

MARCINKIEWICZ, J. In vitro cytokine release by activated murine peritoneal macrophages: Role of prostaglandins in the differential regulation of tumor necrosis factor alpha, interleukin-1, and interleukin-6. Cvtokine 3, 327-332, 1991 .

MAZZEI, G.J., BERNASCONI, L.M., LEWIS, C., MERMOD, J.J., KINDLER, V., and SHAW, A.R. Human granulocyte-macrophage colony-stimulating factor plus phorbol acetate stimulate a promyelocytic cell line to produce an IL-1 inhibitor. $J$. Immunol. 145, 585-591, 1990.

MELNICOFF, M.J., HORAN, P.K., and MORAHAN, P.S. Kinetics of changes in peritoneal cell populations following acute inflammation. Cell Immunol. 118, 178-191, 1989.

MOORADIAN, A.D., REED, R.L., and SCUDERI, P. Serum levels of tumor necrosis factor alpha, interleukin1 alpha and beta in healthy elderly subjects. Age 14, 61-64, 1991.

NORMAN, D.C., YAMAMURA, R.H., and YOSHIKAWA, T.T. Fever response in old and young mice after injection of interleukin-1. J. Gerontol. 43, M80-M85, 1988.

NORTH, R.J. The concept of the activated macrophage. J. Immunol. 121, 806-809, 1978. 
NOVICK, D., ENGELMANN, H., WALLACH, D., and RUBINSTEIN, M. Soluable cytokine receptors are present in normal human urine. J. Exp. Med. 170, 1409-1414, 1989.

OGMUNDSDOTTIR, H.M. Mechanisms of macrophage activation. Clin. Exp. Immunol. 40, 223-234, 1980.

PEETRE, C., THYSELL, H., GRUBB, A., and OLSSON, I. A tumor necrosis factor binding protein is present in human biological fluids. Eur. J. Haematol. 41, 414-419, 1988.

PERKINS, E.H. Phagocytic activity of aged mice. J. Reticuloendothel. Soc. 9, 642-643, 1971.

PETREQUIN, P.R. and JOHNSON, A.G. Macrophage activation by adjuvants in aging mice. J. Leukoc. Biol. 35, 251-263, 1984.

PUTNAM, A.D., and PETERSON, T.C. Effect of aging and other factors on monocyte aryl hydrocarbon hydrolase activity. Mech Ageing Dev. 60, 61-74, 1991.

RASMUSSEN, S.E., RHODES, J.M., BENNEDSEN, J., and OLESEN LARSEN, S. Fractionation of untreated and inflammatory murine peritoneal macrophages on discontinuous Percoll density gradients. A.P.M.I.S. 91C, 299-304, 1983.

REED, D. and BURNHAM, K. Tumor-associated macrophages share in vitro growth characteristics with resident but not elicited macrophages. J. Leukoc. Biol. 50, 167-175, 1991.

ROSENBERG, J.S., GILMAN, S.C., and FELDMAN, J.D. Effects of aging on cell cooperation and lymphocyte responsiveness to cytokines. $J$. Immunol. 130, 1754-1758, 1983.

RUCO, L.P. and MELTZER, M.S. Macrophage activation for tumor cytotoxicity: Increased lymphokine responsiveness of peritoneal macrophages during acute inflammation. J. Immunol. $120,1054-1062,1978$.

RUDD, A.G., and BANERJEE, D.K. Interleukin- 1 production by human monocytes in aging and disease. Age Ageing 18, 43-46, 1989.

RUSSO, C., SCHWAB, R., and WEKSLER, M.E. Immune dysregulation associated with aging. Aging Immun. Infect. Dis. 2, 211-216, 1990.

SECKINGER, P., ISAAZ, S., and DAYER, J.M. A human inhibitor of tumor necrosis factor $\alpha . J$. Exp. Med. 167, 1511-1516, 1988.

SPITALNY, G.L. Dissociation of bactericidal activity from other functions of activated macrophages in exudates induced by thioglycolate. Infect. Immun. 34, 274-284, 1981.

SVENSON, M., BAGGE HANSEN, M., and BENDTZEN, K. Distribution and characterization of autoantibodies to interleukin-1 $\alpha$ in normal human sera. Scand. J. Immunol. 32, 695-701, 1990.

TACHIBANA, K., CHEN, G.-J., HUANG, D.S., SCUDERI, P., and WATSON, R.R. Production of tumor necrosis factor $\alpha$ by resident and activated murine macrophages. J. Leukoc. Biol. 51, 251-255, 1992.

TANNENBAUM, C.S., NURMI-McKERNAN, L., and LARGEN, M.T. Differential protein synthesis by murine peritoneal macrophages elicited by various stimuli. J. Leukoc. Biol. 41, 527-538, 1987.

TOMIOKA, H., and SAITO, H. Characterization of immunosuppressive functions of murine peritoneal macrophages induced with various agents. J. Leukoc. Biol. 15, 24-31, 1992.

VAN FURTH, R. Cell kinetic and genetic aspects of macrophage activation. Ann. Inst. Pasteur/Immunol. 137C, 192-197, 1986.

WUSTROW, T.P.U., DENNY, T.N., FERNANDES, G., and GOOD, R.A. Changes in macrophages and their functions with aging in C57BL/6J, AKR/J, and SJL/J mice. Cell. Immunol. 69, 227-234, 1982. 